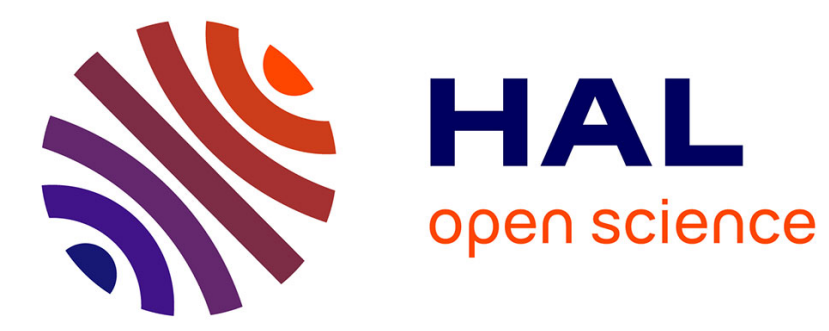

\title{
Iron-catalyzed hydrosilylation of diacids in the presence of amines: a new route to cyclic amines
}

Duo Wei, Chakkrit Netkaew, J Wu, Christophe Darcel

\section{To cite this version:}

Duo Wei, Chakkrit Netkaew, J Wu, Christophe Darcel. Iron-catalyzed hydrosilylation of diacids in the presence of amines: a new route to cyclic amines. ChemCatChem, 2020, 12 (21), pp.5449-5455. $10.1002 /$ cctc. 202000881 . hal-02957751

\section{HAL Id: hal-02957751 \\ https://hal.science/hal-02957751}

Submitted on 8 Oct 2020

HAL is a multi-disciplinary open access archive for the deposit and dissemination of scientific research documents, whether they are published or not. The documents may come from teaching and research institutions in France or abroad, or from public or private research centers.
L'archive ouverte pluridisciplinaire HAL, est destinée au dépôt et à la diffusion de documents scientifiques de niveau recherche, publiés ou non, émanant des établissements d'enseignement et de recherche français ou étrangers, des laboratoires publics ou privés. 


\title{
Iron-catalyzed hydrosilylation of diacids in the presence of amines: a new route to cyclic amines
}

\author{
Duo Wei, ${ }^{[a]}$ Chakkrit Netkaew, ${ }^{[a]}$ Jiajun Wu, ${ }^{[a]}$ and Christophe Darcel *[a]
}

Dedicated to Prof. Pierre H. Dixneuf for his meaningful contribution to organometallic chemistry and ruthenium catalysis

\author{
[a] Dr. D. Wei, C. Netkaew, J. Wu, Prof. Dr. C. Darcel \\ Univ Rennes, CNRS, ISCR \\ (Institut des Sciences Chimiques de Rennes) \\ UMR 6226, F-35000, Rennes, France \\ E-mail: christophe.darcel@univ-rennes1.fr \\ Supporting information for this article is given via a link at the end of the document.
}

\begin{abstract}
Cyclic amines (such as pyrrolidines, piperidines and azepanes) are present in a large class of natural products and bioactive molecules. Herein, we present a novel chemoselective strategy for building $\mathrm{N}$-substituted cyclic amines via iron catalyzed one-pot hydrosilylation starting from readily available dicarboxylic acids and amines, with hydrosilanes as the hydride sources. The described methodology allows the preparation of a wide range of $\mathrm{N}$ alkylated and arylated cyclic amine derivatives (including pharmaceuticals Fenpiprane and Prozapine) in moderate to excellent yields, starting from inexpensive succinic, glutaric, and adipic acids with dimethyl carbonate as a green solvent.
\end{abstract}

Amines are crucial derivatives in the area of molecular chemistry as demonstrated by their preponderance in pharmaceuticals, agrochemicals, dyes, and material science. Furthermore, in 2015, 170 of the top 200 drugs, representing more than US $\$ 500$ million retail sales contained a nitrogen atom or an amino moiety in their structure. ${ }^{[1]}$ (Figure 1) Thus, the synthesis of amine compounds is still a crucial task in modern chemistry. ${ }^{[2]}$

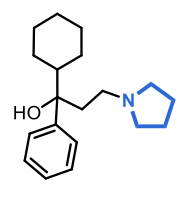

Procyclidine anti-chlolinergic drug

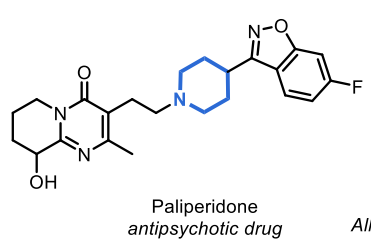

antipsychotic drug

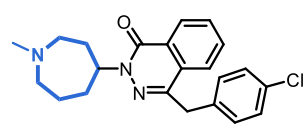

Azelastine Allergic rhinitis and conjunctivitis drug
Figure 1. Examples of cyclic amines as drugs.

Over the numerous methodologies developed, well exemplified catalytic reduction of carboxylic derivatives such as acids or amides is still an important area of research mainly with non-noble transition metals such as iron, manganese or cobalt. More particularly, the reduction of carboxamides is far away the most challenging to perform due to the lower electrophilicity of the carbonyl group and the chemoselectivity issues. Indeed, the reduction of amides can lead to the formation of amines, imines, enamines or nitriles by $\mathrm{C}-\mathrm{O}$ bond cleavage, whereas alcohols, aldehydes and degraded amines are obtained by cleavage of the C-N bond (Scheme 1). ${ }^{[3]}$

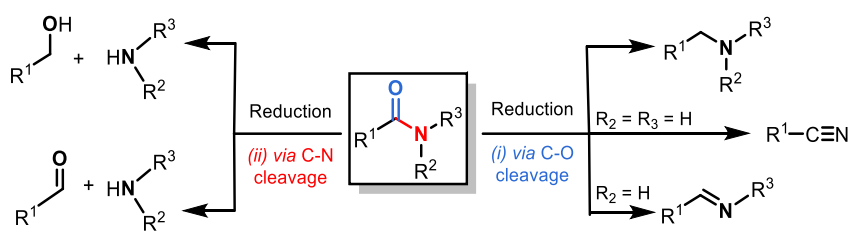

Scheme 1. Two pathways for the reductive transformations of amides: (i) to amines via dissociation of the $\mathrm{C}-\mathrm{O}$ bond and (ii) to alcohols and degraded amines via cleavage of the $\mathrm{C}-\mathrm{N}$ bond.

Additionally, catalytic hydrogenation of amides still suffered from drastic and harsh reaction conditions (elevated temperatures, high hydrogen pressures), and moderate level of chemoselectivity (deoxygenation vs hydrogenolysis pathways). ${ }^{[4]}$ Since the first report on the hydrogenolysis of amides into amines and alcohols with ruthenium pincer catalysts, ${ }^{[5]}$ such $\mathrm{Ru}$ based catalysts have shown promising activities for the selective hydrogenation of amides to amines. ${ }^{[6]}$ For the other reduction pathway involving a $\mathrm{C}-\mathrm{O}$ bond cleavage, a significant breakthrough was made by Cole-Hamilton ${ }^{[7,8]}$ using a catalyst based on $\mathrm{Ru}(\mathrm{acac})_{3}$ and triphos (1,1,1-tris(diphenylphosphinomethyl)ethane) in the presence of a stoichiometric amount of methanesulfonic acid able to perform the selective deoxygenation of aromatic amides leading to the corresponding amines (10-40 bar $\left.\mathrm{H}_{2}, 200-220{ }^{\circ} \mathrm{C}\right)$. The use of an additional Lewis acid such as $\mathrm{Yb}(\mathrm{OTf})_{3},{ }^{\left[{ }^{[0]}\right.} \mathrm{BF}_{3} \cdot \mathrm{Et}_{2} \mathrm{O},{ }^{[10]}$ or $\mathrm{B}\left(\mathrm{C}_{6} \mathrm{~F}_{5}\right)_{3}{ }^{[11]}$ as cocatalysts had also a beneficial effect on the activity and the chemoselectivity for the hydrogenation of secondary and tertiary amides then performed in less drastic conditions. Recently, a PNP-manganese catalyst associated to a Lewis acid was reported for the same reaction by Milstein $\left(150^{\circ} \mathrm{C}, 50\right.$ bar of $\left.\mathrm{H}_{2}\right)^{\left[{ }^{[12]}\right.}$

Iron can also be employed for the hydrogenation of amides. ${ }^{[13]}$ Indeed, in 2016, Milstein reported the first example of a homogeneous iron-catalyzed hydrogenation of $\mathrm{N}$-substituted 2,2,2-trifluoroacetamides using an iron-pincer (PNP) catalyst leading to the corresponding amines and trifluoroethanol through 
C-N bond cleavage $\left(140{ }^{\circ} \mathrm{C}, 60\right.$ bar of $\left.\mathrm{H}_{2}\right) \cdot{ }^{[14]}$ By contrast, performing the reduction under hydrosilylation conditions ${ }^{[15]}$ permitted to reverse the chemoselectivity since the $\mathrm{C}-\mathrm{O}$ bond cleavage was favoured as demonstrated by the pioneering contributions of Nagashima ${ }^{[16]}$ and Beller ${ }^{[17]}$ using $\mathrm{Fe}_{3}(\mathrm{CO})_{12}$ or $\mathrm{Fe}(\mathrm{CO})_{5}$ as pre-catalysts with either PMHS or TMDS as the hydride source. Similar results could be obtained using iron-NHC complex $\left[\mathrm{CpFe}(\mathrm{CO})_{2}(\mathrm{IMes})\right][\mathrm{I}],{ }^{[18]} \quad[$ bis-(N-Dipp-imidazole-2ylidene)methylene-Fe( $\eta^{6}$-benzene $\left.)\right],{ }^{[19]}$ and in situ prepared species from $\mathrm{Fe}(\mathrm{OAc})_{2}$, [Ph-HEMIM][OTf] and PMHS. ${ }^{[20]}$ Notably, the association of two catalytic systems $\left[\mathrm{NHEt}_{3}\right]\left[\mathrm{Fe}_{3} \mathrm{H}(\mathrm{CO})_{11}\right]$ and $\mathrm{Fe}(\mathrm{OAc})_{2}$ /terpyridine efficiently reduced primary amides to primary amines. ${ }^{[21]}$

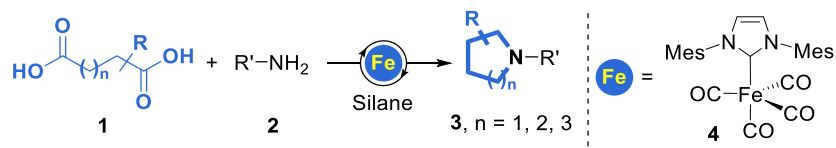

Scheme 2. Novel route to $\mathrm{N}$-substituted cyclic amines via iron-catalysed hydrosilylation of diacids with amines.

Following our recent development on cyclic amine synthesis via iron-catalyzed one-pot sequential transformations under hydrosilylation conditions starting from keto-acids or $\omega$-amino fatty acid derivatives, ${ }^{[22]}$ we herein report the use of diacids as the starting substrates to prepare pyrrolidines, piperidines and azepanes. (Scheme 2) Indeed, over the other alternative methods involving such iron-catalyzed reductive amination sequences, diols can be also envisaged as starting materials. In this area, significant breakthrough has been made in the development of methods for the cyclization of primary amines starting from diols via hydrogen borrowing catalyzed with noble metals, ${ }^{[23]}$ base metals, ${ }^{[24]} \mathrm{Y}-\mathrm{Al}_{2} \mathrm{O}_{3}{ }^{[25]}$ as well as organic catalysts. ${ }^{[26]}$ The advantages of such methodologies were clearly atom-economic and without generation of harmful waste (only water as by-product) even if most of these systems required high reaction temperature. Additionally, Barta reported elegant methodologies based on hydrogen borrowing pathways involving iron-catalyzed alkylation of amines with alcohols ${ }^{[27]}$ or decarboxylative $N$-alkylation of cyclic $\alpha$-amino acids. ${ }^{[28]}$

On the other hand, carboxylic acids can be interesting alternative starting materials for $\mathrm{N}$-alkylation of amines. Indeed, a straightforward catalytic $\mathrm{N}$-alkylation of amines with carboxylic acids was reported by Beller et al. in 2014 using Karstedt's type catalyst and hydrosilanes as reducing reagents. ${ }^{[29]}$ Even if diacids are more readily available, to the best of our knowledge, the direct hydrosilylation of diacids with amines yielding $\mathrm{N}$ substituted cyclic amines remains unknown to date. Nevertheless, it must be noticed that the reduction of diesters with anilines under hydrogenation conditions led to $\mathrm{N}$-aromatic heterocycles when catalyzed by $\mathrm{Ru}(\mathrm{acac})_{3}$ associated with triphos. ${ }^{[30]}$ However harsh reaction conditions $\left(220{ }^{\circ} \mathrm{C}\right)$ were generally required and its scope was limited to aniline derivatives.

Based on our previous contributions, we then began our initial optimization work using the iron(0) $\mathrm{N}$-heterocyclic carbene complex $\mathrm{Fe}(\mathrm{CO})_{4}(\mathrm{IMes}) \mathbf{4}$ as the catalyst $(5 \mathrm{~mol} \%$ ) for the reaction of glutaric acid $\mathbf{1 a}$ with aniline $\mathbf{2 a}$ in the presence of $\mathrm{PhSiH}_{3}$ (6 equiv.). Under solvent free conditions, after $20 \mathrm{~h}$ at $100{ }^{\circ} \mathrm{C}$ upon visible light activation $(24 \mathrm{~W}$ compact fluorescent lamp), both conversion (70\%) and selectivity were moderate as a mixture of $\mathrm{N}$-phenylpiperidine $\mathbf{3 a}, \mathrm{N}$-phenylglutarimide $\mathbf{5 a}$ and $N$-phenyl-2-piperidone 6 a was obtained in a ratio of $54 / 11 / 5$ (Table 1, entry 1). Performing the reaction in toluene under similar conditions didn't permit to increase the conversion, but the selectivity towards the formation of desired product $3 \mathbf{a}$ increased to $67 \%$ yield, along with $3 \%$ of 6 a. Conducting the transformation at $110{ }^{\circ} \mathrm{C}$ for $20 \mathrm{~h}$ permitted to convert $75 \%$ of the starting materials and obtained $\mathbf{3 a}$ exclusively $(75 \%$, Table 1 , entry 3).

Table 1. Catalyzed hydrosilylation of glutaric acid with aniline. ${ }^{[a]}$

\begin{tabular}{|c|c|c|c|c|c|c|c|}
\hline & $\mathrm{O}_{\mathrm{OH}}$ & $\mathrm{Ph}-\mathrm{NH}_{2}$ & $\begin{array}{l}\left.5 \mathrm{~mol}^{\circ}\right) \\
\mathrm{hSSiH}_{3} \\
0^{\circ} \mathrm{C}, \mathrm{hv} \\
20 \mathrm{~h}\end{array}$ & & $6 a$ & & $3 a$ \\
\hline \multirow{2}{*}{ Entry } & \multirow{2}{*}{$\begin{array}{l}\mathrm{PhSiH}_{3} \\
\text { [equiv.] }\end{array}$} & \multirow{2}{*}{ Solvent } & \multirow{2}{*}{$\begin{array}{c}\text { Additive } \\
\text { [mol\%] }\end{array}$} & \multirow{2}{*}{$\begin{array}{l}\text { Conv. } \\
{[\%]^{[a]}}\end{array}$} & \multicolumn{3}{|c|}{ Yield [\%] ${ }^{[a]}$} \\
\hline & & & & & $5 a$ & $6 a$ & $3 a$ \\
\hline $1^{[\mathrm{b}]}$ & 6 & Neat & - & 70 & 11 & 5 & 54 \\
\hline $2^{[b]}$ & 6 & Toluene & - & 70 & 0 & 3 & 67 \\
\hline 3 & 6 & Toluene & - & 75 & 0 & 0 & 75 \\
\hline 4 & 6 & Me-THF & - & 70 & 0 & 0 & 70 \\
\hline 5 & 6 & Dioxane & - & 70 & 0 & 0 & 70 \\
\hline 6 & 6 & DMC & - & 72 & 0 & 0 & 72 \\
\hline $7^{[c]}$ & 6 & Toluene & - & 69 & 69 & 0 & 0 \\
\hline 8 & 4 & Toluene & - & 40 & 12 & 4 & 24 \\
\hline 9 & 2 & Toluene & - & 38 & 25 & 5 & 8 \\
\hline $10^{[d]}$ & 6 & DMC & - & 50 & 50 & 0 & 0 \\
\hline $11^{[\mathrm{d}]}$ & - & DMC & - & 0 & 0 & 0 & 0 \\
\hline 12 & - & DMC & - & 0 & 0 & 0 & 0 \\
\hline 13 & 6 & DMC & $\mathrm{FeCl}_{3}(10)$ & 32 & 32 & 0 & 0 \\
\hline 14 & 6 & DMC & $\mathrm{Fe}(\mathrm{OTf})_{3}(10)$ & 26 & 26 & 0 & 0 \\
\hline 15 & 6 & DMC & $\mathrm{FeCl}_{2}(10)$ & 71 & 0 & 0 & 71 \\
\hline 16 & 6 & DMC & $\mathrm{Fe}(\mathrm{OTf})_{2}(10)$ & 83 & 0 & 0 & 83 \\
\hline 17 & 6 & DMC & $\mathrm{Fe}(\mathrm{OTf})_{2}(20)$ & 90 & 0 & 0 & 90 \\
\hline 18 & 6 & DMC & $\mathrm{Fe}(\mathrm{OTf})_{2}(30)$ & 84 & 17 & 0 & 67 \\
\hline
\end{tabular}

[a] General conditions: 4 (5 mol\%), $\mathbf{1 a}(0.5 \mathrm{mmol}), \mathbf{2 a}(0.5 \mathrm{mmol}), \mathrm{PhSiH}_{3}(0-6$ equiv.) and solvent $(1 \mathrm{~mL})$, visible light irradiation, $110^{\circ} \mathrm{C}, 20 \mathrm{~h}$; then hydrolysis $(\mathrm{THF} / \mathrm{NaOH} 2 \mathrm{~N})$. The conversions and yields were determined by ${ }^{1} \mathrm{H}$ NMR using dibromomethane as the internal standard. [b] $100^{\circ} \mathrm{C}$. [c] $\left[\mathrm{CpFe}(\mathrm{CO})_{2}(\mathrm{IMes})\right][\mathrm{l}] 7(5 \mathrm{~mol} \%)$ as the catalyst. [d] in the absence of $\mathrm{Fe}$ catalyst 4.

Substituting toluene by 2-Me-THF, 1,4-dioxane or dimethylcarbonate (DMC) did not increased the conversion, even if 3a was still exclusively obtained (70-72\%; Table 1, entries 4-6). Nevertheless, since DMC gave comparable efficiency, its greener character prompted us to select it for the scope of this transformation. ${ }^{[31]}$ Interestingly, using an iron(II) complex such as $\left[\mathrm{CpFe}(\mathrm{CO})_{2}(\mathrm{IMes})\right][\mathrm{I}] 7$ (5 mol\%) under similar conditions in toluene at $110{ }^{\circ} \mathrm{C}, 69 \%$ of glutaric acid 1a was converted, but the chemoselectivity was switched as only the $\mathrm{N}$-phenylglutarimide 5a was obtained, showing that this iron(II) catalyst was able to promote only the transamidation reaction, but not the reduction of $5 \mathbf{a}$ leading to $\mathbf{6 a}$ then $\mathbf{3 a}$ (Table 1 , entry 7). Additionally, reducing the amount of phenylsilane to 4 equiv. decreased the efficiency of the reaction as only $40 \%$ of conversion was observed and a mixture of $\mathbf{3 a}, \mathbf{5 a}$ and $\mathbf{6 a}$ was obtained in a ratio of $24 / 12 / 4$. With 2 equiv. of $\mathrm{PhSiH}_{3}$, similar conversion (38\%) of 1a was observed, but with $\mathbf{5 a}(25 \%)$ as the major product (Table 1 , entries 8-9). 
Noticeably, with 6 equiv. of phenylsilane, the reaction reached $50 \%$ conversion in the absence of catalyst 4 leading to exclusively $N$-phenylglutarimide $\mathbf{5 a}$ (Table 1 , entry 10 ), whereas in the absence of both silane and Fe catalyst, or using $5 \mathrm{~mol} \%$ of 4 without silane, no reaction occurred. (Table 1, entries 11-12). These results seem to indicate that the excess of $\mathrm{PhSiH}_{3}$ promotes the formation of imide 5 a (see also SI Scheme S1), via the intermediate of silylated diester obtained from diacid derivatives. Taking into account that even if the conversion were not complete when using $\mathbf{4}$ as catalyst, $\mathrm{N}$-phenylpiperidine $\mathbf{3 a}$ was obtained solely, indicating that the reduction of $5 \mathbf{a}$ and $6 \mathbf{a}$ was faster than the formation of 5 a via transamidation between $\mathbf{1 a}$ and $\mathbf{2 a}$, making the latter the rate-limiting step.

Lewis acids are known to promote the (trans)amidation of carboxylic acid derivatives with anilines. ${ }^{[32]}$ Thus, several Lewis acids were evaluated in this reaction in association with the $\mathrm{Fe}(0)$ catalyst 4. Using iron(III) based Lewis acids such as $\mathrm{FeCl}_{3}$ or $\mathrm{Fe}(\mathrm{OTf})_{3}(10 \mathrm{~mol} \%)$ led to disappointing results as only partial conversions into imide 5a were observed (32 and 26\%, respectively, Table 1, entries 13-14). Among the trials with different Lewis acids (SI Table S1), Fe(OTf $)_{2}$ exhibited the most promising results: using $\mathrm{Fe}(\mathrm{OTf})_{2}(10 \mathrm{~mol} \%)$ with phenylsilane (6 equiv.) increased the conversion to $83 \%$ and $\mathrm{N}$ phenylpiperidine 3 a was exclusively obtained (Table 1, entry 16). Increasing the $\mathrm{Fe}(\mathrm{OTf})_{2}$ amount to $20 \mathrm{~mol} \%$ enhanced the yield of $3 \mathbf{a}$ to $90 \%$, while the use of $30 \mathrm{~mol} \%$ of $\mathrm{Fe}(\mathrm{OTf})_{2}$ has a detrimental effect on both the reactivity and selectivity $(84 \%$ conversion, $\mathbf{5 a}: \mathbf{3 a}=\mathbf{1 7}: 67$, Table 1 , entries $17-18)$. Thus, the optimized conditions to obtain $\mathrm{N}$-arylpiperidine were $5 \mathrm{~mol} \%$ of 4 in combination with $20 \mathrm{~mol} \%$ of $\mathrm{Fe}(\mathrm{OTf})_{2}$ and 6 equiv. of phenylsilane in DMC at $110^{\circ} \mathrm{C}$ for $20 \mathrm{~h}$. It is worth mentioning that attempts with different hydrosilanes such as $\mathrm{Ph}_{2} \mathrm{SiH}_{2}, \mathrm{Et}_{3} \mathrm{SiH}$, $\mathrm{Me}_{2} \mathrm{PhSiH}$, PMHS (polymethylhydrosiloxane), TMDS (1,1,3,3tetramethyldisiloxane) gave no conversion of aniline.

Table 2. Hydrosilylation of glutaric acid with cyclohexylamine. ${ }^{[a]}$

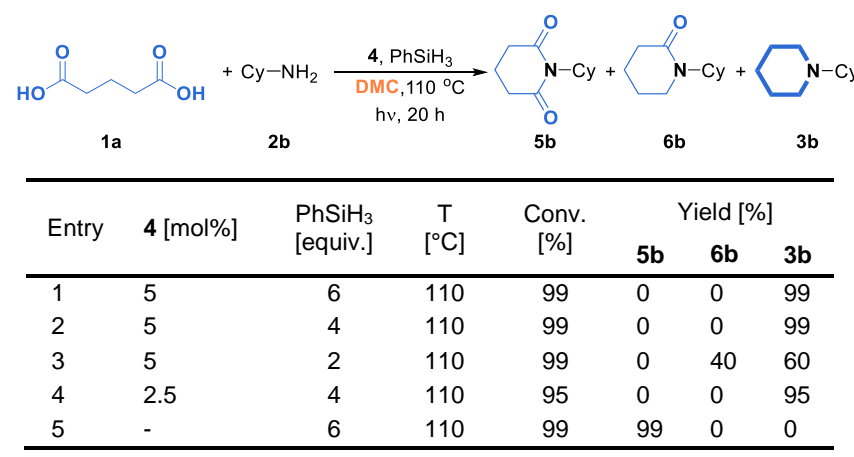

[a] General conditions: 4 (0-5 mol\%), $\mathbf{1 a}(0.5 \mathrm{mmol}), \mathbf{2 a}(0.5 \mathrm{mmol}), \mathrm{PhSiH}_{3}$ (26 equiv.) and DMC $(1 \mathrm{~mL})$, visible light irradiation, $110{ }^{\circ} \mathrm{C}, 20 \mathrm{~h}$; then hydrolysis $(\mathrm{THF} / \mathrm{NaOH} 2 \mathrm{~N})$. The conversions and yields were determined by ${ }^{1} \mathrm{H}$ NMR using dibromomethane as the internal standard.

We then focussed on the reaction of alkylamine (cyclohexylamine $\mathbf{2 b}$ ) with glutaric acid $\mathbf{1 a}$ in order to synthesize $\mathrm{N}$-alkylpiperidines (Table 2). The optimization study was firstly performed using 4 as the catalyst (5 mol\%) in the presence of $\mathrm{PhSiH}_{3}$ (6 equiv.) in DMC. After $20 \mathrm{~h}$ at $110{ }^{\circ} \mathrm{C}, \mathrm{N}$ cyclohexylpiperidine $\mathbf{3 b}$ was generated in quantitative NMR-yield (Table 2, entry 1), notably without the production of other intermediates: $\mathrm{N}$-cyclohexylglutarimide $\mathbf{5 b}$ and $\mathrm{N}$-cyclohexyl-2- piperidone $\mathbf{6 b}$, and without the use of Lewis acid. The amount of $\mathrm{PhSiH}_{3}$ can be decreased to 4 equiv. without any loss of activity and selectivity, as $\mathbf{3} \mathbf{b}$ was still obtained quantitatively. (Table 2, entry 2) However, the selectivity dropped when decreasing the amount of $\mathrm{PhSiH}_{3}$ to 2 equiv. or the catalyst loading to $2.5 \mathrm{~mol} \%$ (Table 2, entries 3-4). Finally, in the absence of the catalyst 4, 5b was found to be the sole product, demonstrating that $\mathrm{Fe}$ catalyst $\mathbf{4}$ was crucial to produce $\mathbf{3 b}$.

With the optimized conditions for the catalyzed hydrosilylation of diacids in the presence of arylamines and alkylamines (Table 1, entry 17 , and Table 2, entry 2 , respectively) in hand, the substrate scope and its limitation were next studied (Table 3 for alkylamines, Table 4 for arylamines).

Starting from glutaric acid 1a, various alkylamines such as cyclohexylamine, 1-hexylamine and benzylamine can be applied leading to the corresponding piperidines in excellent isolated yields (3b-d, 93-95\%, Table 3). The substitution of the benzyl moiety with electron donating or withdrawing groups such as methoxy or trifluoromethyl had nearly no influence on the efficiency of the transformation, leading to $3 \mathbf{e}$ and $\mathbf{3 f}$ in $91 \%$ and $85 \%$ yields, respectively. Additionally, heteroaromatic moiety, for instance, furyl and benzimidazolyl groups can be tolerated as $\mathbf{3 g}$ and $3 \mathrm{~h}$ were generated in $91 \%$ and $80 \%$ yields, respectively. Noticeably, increasing the steric hindrance of the amine partner decreased the efficiency of the reaction: indeed, using 2,4,6trimethylbenzylamine or $\alpha$-methylbenzylamine led to the corresponding piperidines $\mathbf{3 i}$ and $\mathbf{3} \mathbf{j}$ in moderate yields, $73 \%$ and $68 \%$, respectively.

Table 3. Hydrosilylation of diacids in the presence of aliphatic primary amines. $^{[\mathrm{a}]}$

\begin{tabular}{|c|c|c|c|}
\hline O & & $\frac{4\left(5 \mathrm{~mol}^{2}\right), \mathrm{PhSiH}_{3} \text { (4 equiv.) }}{\mathrm{DMC}, 110^{\circ} \mathrm{C} \text { hy } 20 \mathrm{~h}}$ & \\
\hline $\begin{array}{l}1 \mathrm{1}, \mathrm{n}=2 \\
1 \mathrm{~b}, \mathrm{n}=1 \\
1 \mathrm{c}, \mathrm{n}=3\end{array}$ & 2 & & $\begin{array}{l}3, n=2 \\
8, n=1 \\
9, n=3\end{array}$ \\
\hline
\end{tabular}

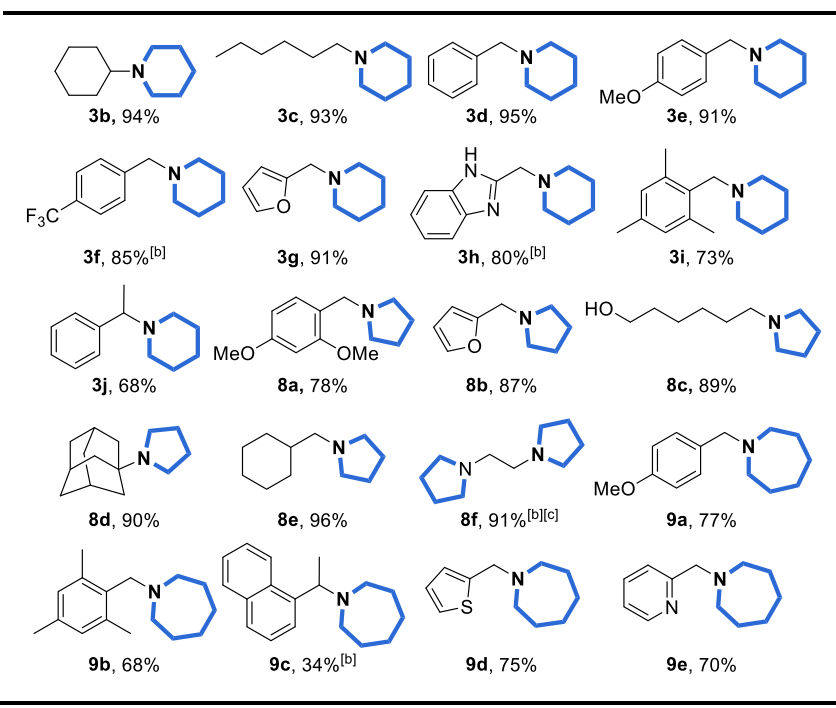

[a] General conditions: 4 (5 mol\%), diacid 1 (0.5 mmol), amine 2 (0.5 mmol), $\mathrm{PhSiH}_{3}$ (4 equiv.) and $\mathrm{DMC}(1 \mathrm{~mL})$, visible light irradiation, $110^{\circ} \mathrm{C}, 20 \mathrm{~h}$; then hydrolysis (THF/NaOH $2 \mathrm{~N}$ ). Isolated yields of the products are shown. [b] NMR yield. [c] succinic acid $\mathbf{1 b}(1.0 \mathrm{mmol}, 2$ equiv. to amine 2$), \mathrm{PhSiH}_{3}$ (8 equiv.), $48 \mathrm{~h}$. 
Starting from succinic acid $\mathbf{1 b}$, pyrrolidines $\mathbf{8}$ can be also efficiently prepared in one step. Thus, $\mathbf{8 a}$ and $\mathbf{8 b}$ can be synthesized from the corresponding amines, 2,4dimethoxybenzylamine and furfurylamine, in $78 \%$ and $87 \%$ yields, respectively. Remarkably, using an amino-alcohol such as 6-aminohexanol, a chemoselective transformation occurred as the pyrrolidine $\mathbf{8 c}$ bearing a pending hydroxyl group was prepared in $89 \%$ yield. Furthermore, using more steric hindered 1 -adamentylamine, $8 \mathbf{d}$ was obtained in $90 \%$ yield. As expected, cyclohexanemethylamine was a suitable substrate leading to $\mathbf{8 e}$ in $96 \%$ yield. Interestingly, ethylene-diamine also reacted selectively with succinic acid giving the corresponding bispiperidine $8 \mathrm{f}$ in $91 \%$ yield.

Larger cyclic amines, such as azepanes, can be also produced in moderate to good yields using this methodology: starting from adipic acid 1c, azepanes $\mathbf{9 a}$ and $\mathbf{9 b}$ were obtained in $77 \%$ and $68 \%$ yields when reacted with $p$-methoxybenzylamine and 2,4,6-trimethylbenzylamine (Table 3). With the more steric hindered 1-(1-naphyl)ethylamine, 9c was detected in a lower yield (34\%), showing that the steric hindrance had a drastic effect on the activity for the azepane formation. The reaction also tolerated heteroaromatic groups such as thienyland pyridyl-methylamine which led to $9 \mathrm{~d}$ and $9 \mathrm{e}$ with $75 \%$ and $70 \%$ yields, respectively. Nevertheless, it should be noticed that unsaturated amines such as allylamine and propargylamine led to unsatisfactory selectivity, as the $\mathrm{C}=\mathrm{C}$ and $\mathrm{C} \equiv \mathrm{C}$ were partially reduced.

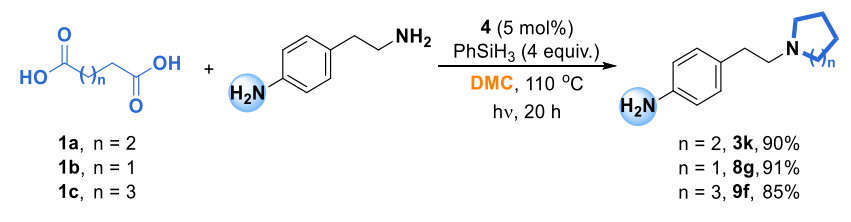

Scheme 3. N-Alkylation of alkylamines bearing aniline moiety.

Since it was potentially competitive to alkylate anilines and aliphatic amines with diacids, we decided to perform the reaction with 4-(2-aminoethyl)aniline as the substrate associated with succinic, glutaric, and adipic acids. (Scheme 3 ) Noticeably, the $\mathrm{N}$-alkylation of aliphatic amine moiety occurred exclusively as the corresponding cyclic amines $\mathbf{3 k}, \mathbf{8 g}$ and $\mathbf{9 f}$ were isolated in $\mathbf{8 5 \% -}$ $91 \%$ yields, leaving aniline group untouched.
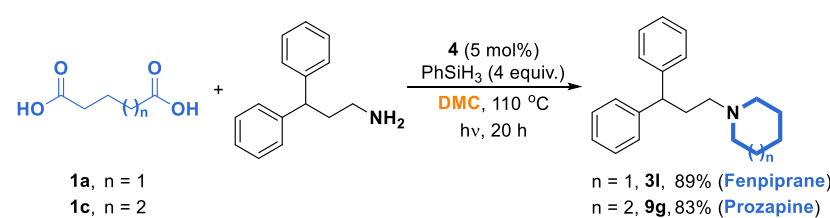

Scheme 4. One-pot catalytic synthesis of Fenpiprane $\mathbf{3 l}$ and Prozapine $\mathbf{9 g}$

Furthermore, we have demonstrated the synthetic utility of this methodology in the preparation of drug molecules Fenpiprane $\mathbf{3} \mathbf{l}$ and Prozapine $\mathbf{9 g}$, which are used to treat functional gastrointestinal disorders, and as antispasmodic drug, respectively ${ }^{[33]}$ (Scheme 4). Thus, reaction of the 3,3- diphenylpropylamine and glutaric acid 1a (adipic acid 1c) afforded $\mathbf{3 l}$ and $\mathbf{9 g}$, in $89 \%$ and $83 \%$ isolated yields.

In order to prepare $\mathrm{N}$-aryl cyclic amines (Table 4), the optimized reaction conditions depicted in Table 1, entry 17 was employed. By reaction of glutaric acid 1a with aniline, $p$-toluidine and 4-(benzyloxy)aniline, the corresponding $N$-arylpiperidines 3a, $3 \mathrm{~m}$ and $3 \mathrm{n}$ were obtained in $80 \%-95 \%$ yields. Good functional group tolerance was achieved starting from $p$-aminophenol, as 30 was isolated in $95 \%$ yield. The transformation can be also conducted with $p$-phenylenediamine yielded the bis-pyrrolidine $3 p$ in $65 \%$. By contrast, the use of 2,4,6-trimethylaniline didn't permit to obtain efficiently the corresponding piperidine $3 q(28 \%)$, indicating that steric hindrance decreased drastically the reactivity. Substituted glutaric acid, like 3-methylglutaric acid 1a' was also a suitable coupling partner with $p$-anisidine, leading to $3 r$ in $61 \%$ yield.

Table 4. Hydrosilylation of diacids in the presence of primary arylamines. ${ }^{[a]}$

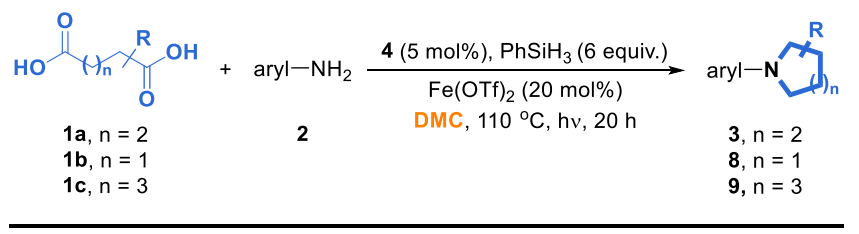<smiles>Cc1ccc(N2CCCCC2)cc1</smiles>

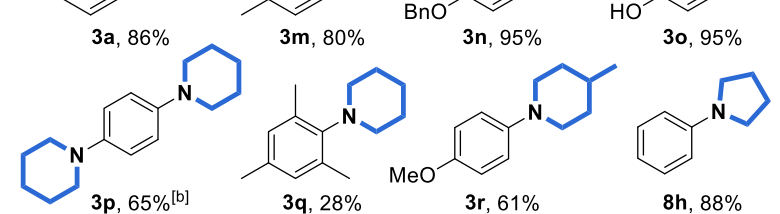<smiles>COc1ccc(N2CCCC2)cc1N(C)c1ccc(N2CCCC2)cc1N(C)c1ccc(N2CCCC2)cc1</smiles><smiles>Fc1cc(F)c(N2CCCC2)c(F)c1</smiles><smiles></smiles><smiles>c1ccc(N2CCCC2)nc1</smiles>

8 p, $50 \%$<smiles>O=[N+]([O-])c1ccc(N2CCCC2)cc1</smiles>

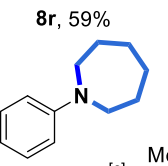

$8 \mathrm{u}, 0$

[a] General conditions: 4 (5 mol\%), 1 (0.5 mmol), Fe(OTf) 2 (20 mol\%), amine $2(0.5 \mathrm{mmol}), \mathrm{PhSiH}_{3}$ (6 equiv.) and $\mathrm{DMC}(1 \mathrm{~mL})$, visible light irradiation, $110{ }^{\circ} \mathrm{C}, 20 \mathrm{~h}$; then hydrolysis $(\mathrm{THF} / \mathrm{NaOH} 2 \mathrm{~N})$. Isolated yields of the products are shown. [b] glutaric acid $1 \mathrm{a}\left(1.0 \mathrm{mmol}, 2\right.$ equiv.), $\mathrm{PhSiH}_{3}$ (12 equiv.), $48 \mathrm{~h}$. [c] $\mathrm{Fe}(\mathrm{OTf})_{2}(50 \mathrm{~mol} \%)$.

The reaction of succinic acid $\mathbf{1 b}$ with aniline, $p$-methoxy, $p$ dimethylamino, $p$-fluoro, $o$-fluoro, $p$-chloro and $p$-bromoanilines led to pyrrolidines $\mathbf{8 h - n}$ in $69-88 \%$ yields, highlighting the functional group tolerance towards electron donating and halogeno groups. However, deiodinated pyrrolidine product was 
mainly obtained starting from 4-iodoaniline. Notably, an important building block for pharmaceuticals such as 3,4(methylenedioxy)aniline was effectively transformed to piperidine 80 in $84 \%$ yield. Electron deficient anilines like otrifluoromethyl and 2,4,6-trifluoroaniline were transformed into pyrrolidines $8 p$ and $8 q$ in moderate yields $(50 \%$ and $57 \%$, respectively). Additionally, o-phenylaniline led to $8 r$ in $59 \%$ yield highlighted the drastic effect of the steric hindrance. Heteroaromatic amine like 2-aminopyridine was also successfully applied leading to $8 \mathrm{~s}$ in $62 \%$ yield. Diacid bearing alkenyl moiety such as cis-4-cyclohexene-1,2-dicarboxylic acid 1b' gave $8 \mathbf{t}$ in $91 \%$ yield, with the remote $\mathrm{C}=\mathrm{C}$ untouched. However, diacid with conjugated $\mathrm{C}=\mathrm{C}$, such as maleic acid and itaconic acid, led to a mixture of products due to the easy reduction of the $\mathrm{C}=\mathrm{C}$ bond. Noticeably, anilines bearing more electron-withdrawing nitro, cyano substituents was not converted into the corresponding product.

Additionally, when adipic acid 1c was used in association with aniline under standard conditions, the desired product $\mathrm{N}$ phenylazepane $\mathbf{9 h}$ was detected in ca. 10\% NMR-yield. Noticeably, diol resulting of the reduction of diacid was observed in GC-MS as a by-product. To overcome the low reactivity of adipic acid with arylamine, $50 \mathrm{~mol} \%$ of $\mathrm{Fe}(\mathrm{OTf})_{2}$ was employed to obtain $9 \mathrm{~h}$ and $9 \mathrm{i}$ in $48 \%$ and $60 \%$ yields, respectively, starting from aniline and $p$-anisidine. 3-Methyladipic acid can also provide $9 \mathbf{j}$ in $52 \%$ yield. Albeit this protocol was quite general for aliphatic diacids, the attempts to perform the reaction of phthalic acid with either alkylamines or arylamines gave a mixture of products including the expected isoindoline products.

Even though the organometallic catalytic process involving the Fe complex $\mathbf{4}$ in catalyzed hydrosilylation reactions has been studied, ${ }^{[34]}$ highlighting the crucial role of the light activation to generate a 16 electron active species able to promote the oxidative addition of the hydrosilane thus generating the related $\mathrm{H}-\mathrm{Fe}-\mathrm{SiR}_{3}$ intermediate which was isolated and characterized, we were interested to gain some insights of the reaction pathways. Then various dicarboxylic acid derivatives were employed as substrates to produce cyclic amines starting from cyclohexylamine $\mathbf{2 b}$ (Table 5).

Table 5. Hydrosilylation of various diacid derivatives with cyclohexylamine. ${ }^{\text {[a] }}$

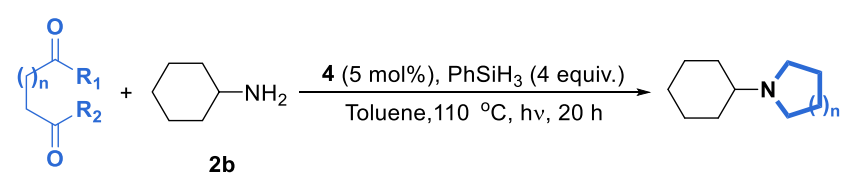

\begin{tabular}{lccccc}
\hline Entry & $\mathrm{R}_{1}$ & $\mathrm{R}_{2}$ & $\mathrm{n}$ & Conv. $^{[\mathrm{a}]}$ & Yield $^{[\mathrm{a}]}$ \\
\hline 1 & $\mathrm{OMe}$ & $\mathrm{OMe}$ & 2 & 16 & 14 \\
2 & $\mathrm{OMe}$ & $\mathrm{OMe}$ & 3 & 6 & 4 \\
3 & $\mathrm{NH}_{2}$ & $\mathrm{OMe}$ & 3 & $\mathrm{n} . \mathrm{d}$. & n.d. \\
4 & $\mathrm{R}_{1}, \mathrm{R}_{2}=-\mathrm{NH}$ (imide) & 1 & n.d. & n.d. \\
$5^{[\mathrm{b}]}$ & $\mathrm{R}_{1}, \mathrm{R}_{2}=-$ - & (anhydride) & 1 & $>99$ & $>99(93)$ \\
\hline
\end{tabular}

[a] General conditions: 4 (5 mol\%), diacid derivative $(0.5 \mathrm{mmol})$, cyclohexylamine $(0.5 \mathrm{mmol}), \mathrm{PhSiH}_{3}$ (4 equiv.) and toluene $(1 \mathrm{~mL})$. visible light irradiation, $110^{\circ} \mathrm{C}, 20 \mathrm{~h}$; then hydrolysis (THF/NaOH $2 \mathrm{~N}$ ). Conversions and yields were detected by ${ }^{1} \mathrm{H}$ NMR using dibromomethane as the internal standard. Isolated yields are shown in parenthesis. [b] using cis-1,2-cyclohexanedicarboxylic anhydride as substrate.
Under the optimized reaction conditions (Table 2, entry 2), dimethyl glutarate and adipate gave the corresponding cyclic amines in $14 \%$ and $4 \%$ NMR yields, respectively (Table 5 , entries 1-2), while methyl adipamate and succinimide were totally inactive (entries 3-4). These results seem to imply that such derivatives were probably not involved as intermediates. Unexpectedly, cis-1,2-cyclohexanedicarboxylic anhydride led to the corresponding cyclic amine $8 \mathbf{v}$ in $93 \%$ isolated yield (entry 5), showing that cyclic anhydride may be a plausible intermediate of the reaction.

Further control experiments were then performed and summarized in Scheme 5. In the absence of amine, succinic acid 1b was converted into succinic anhydride 10 in 49\% NMR yield, in the presence of both $\mathrm{Fe}$ catalyst $4(5 \mathrm{~mol} \%)$ and $\mathrm{PhSiH}_{3}$ (2 equiv.) (Scheme $5 \mathrm{a}$ and SI Table S2). Importantly, molecular hydrogen was detected by in situ ${ }^{1} \mathrm{H}-\mathrm{NMR}$ at $4.47 \mathrm{ppm}$ (Figure $\mathrm{S} 1$ ), and siloxane $\mathrm{PhH}_{2} \mathrm{Si}-\mathrm{O}-\mathrm{SiPhH}_{2}$ was also identified by GCMS. It is described that silyl esters can be generated from dehydrogenative coupling of carboxylic acids and silanes under the catalysis of either transition metals or organo-catalysts. ${ }^{[35]}$

$$
\text { a) }
$$$$
10,42 \%
$$$$
\text { c) }
$$

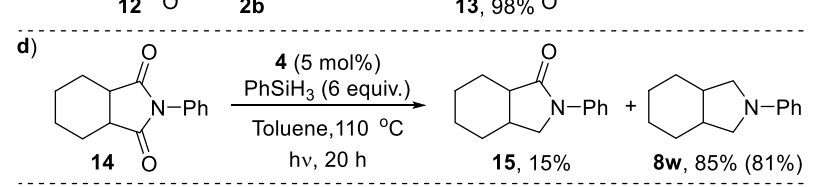<smiles>O=C(O)C1CCCC2C(=O)OC(=O)C12</smiles>

Scheme 5. Control experiments. Conversion and yield were detected by ${ }^{1} \mathrm{H}$ NMR using dibromomethane as the internal standard, isolated yield in parentheses.

Thus, we heated bis(trimethylsilyl)succinate 11 at $110{ }^{\circ} \mathrm{C}$ for $20 \mathrm{~h}$, and as expected, succinic anhydride $\mathbf{1 0}$ was produced in $42 \%$ yield (Scheme $5 \mathrm{~b}$ ), which indicated that cyclic anhydride can be produced via the intermediacy of silylated diester obtained from diacid and silane. Even if it was reported that imides can be prepared by condensation of dicarboxylic anhydrides and primary amines, we set up such reaction starting from cis-1,2-cyclohexane-dicarboxylic anhydride 12 and cyclohexylamine $\mathbf{2 b}$. Indeed, the corresponding imide $\mathbf{1 3}$ was prepared quantitatively (Scheme $5 \mathrm{c}$ ).

Afterwards, the direct hydrosilylation of imide was performed with hexahydro- $N$-phenylphthalimide $\mathbf{1 4}$ as the substrate, under reaction conditions described in Table 1, entry 3. Hexahydro-2phenyl-isoindoline $8 \mathbf{w}$ was thus isolated in $81 \%$ yield. Noticeably, $15 \%$ of amide 15 was also produced as a by-product. 
(Scheme 5d, and SI Table S3) Such results demonstrated that the production of cyclic amines from imide went through the reduction of amide via a Fe-catalyzed sequence. Additionally, since diol was formed during the formation of $\mathrm{N}$-arylazapane (Table 4), it was shown that diol 16 was obtained in $47 \%$ yield by direct hydrosilylation of cyclic anhydride 12 under the same reaction conditions (Scheme $5 \mathrm{e}$ ). In order to rule out a radical process, the addition of TEMPO (1 equiv.) to the reaction was performed. A full conversion of amine starting material was achieved giving $56 \%$ desired products and $41 \%$ amide byproduct along with $3 \%$ of imide (SI Scheme S2), indicating that a radical process may not happen during the catalytic process.

Finally, according to the above control experiments, a proposed reaction pathway is depicted in Scheme 6. The sequence started with the reaction of the diacid 1 such as succinic acid $\mathbf{1 b}$ with hydrosilanes leading to the silylated diester 17 via a dehydrogenative silylation and liberation of $\mathrm{H}_{2}$. After releasing of $\mathrm{R}_{3} \mathrm{Si}-\mathrm{O}-\mathrm{SiR}_{3}$, the cyclic anhydride intermediate $\mathbf{1 0}$ was formed, and reacted with amines to generate the imide $\mathbf{1 8}$, step where the presence of the Fe catalyst 4 was not necessary. Alternatively, cyclic anhydride $\mathbf{1 0}$ could also be reduced into diol 19 with silanes under the catalysis of Fe complex 4 , however it was slower compared with the formation of imide 18. Afterwards, the first reduction of imide $\mathbf{1 8}$ into amide $\mathbf{2 0}$ took place via iron catalysed hydrosilylation. Then amide $\mathbf{2 0}$ was further reduced to the final cyclic amine product $\mathbf{8}$ under the same conditions. ${ }^{\text {[22] }}$ On the other hand, compared with alkylamines, arylamines were less reactive to produce $\mathrm{N}$-arylated cyclic amines, as Lewis acid was required to promote the transamidation step. (Scheme $5 \mathrm{c}$ and SI Table S4).

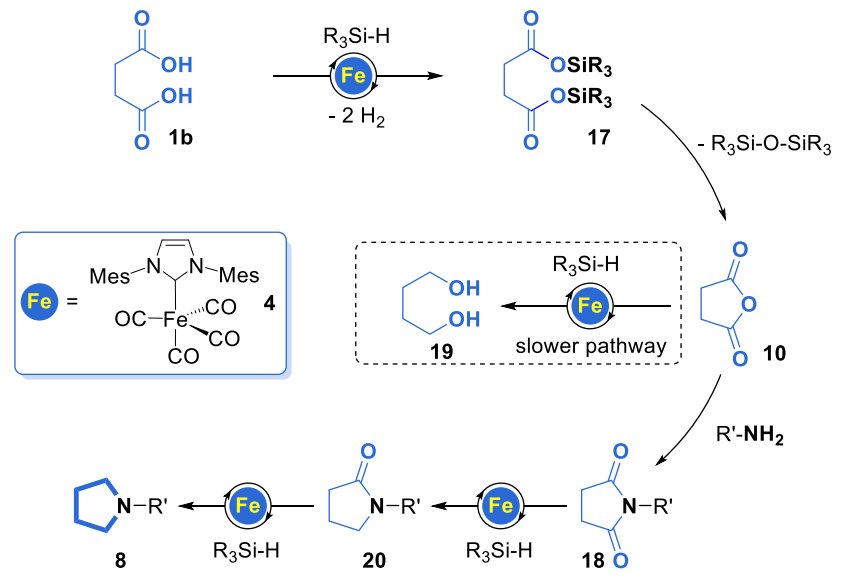

Scheme 6. Proposed possible reaction pathway.

In summary, we have developed for the first time the Fecatalyzed hydrosilylation of diacids in the presence of amines to access $N$-substituted cyclic amines. This method has several advantages: i) it utilizes environmentally benign non-noble transition metal iron based complex as catalyst, ii) it enables onepot synthesis of cyclic amines, iii) it starts from inexpensive dicarboxylic acids and amines, iv) it exhibits good functional group tolerance, v) it allows the production of drug molecules Fenpiprane and Prozapine in good yields, and vi) it proceeds in dimethyl carbonate as a green solvent. Further detailed control experiments have shown that the cyclic anhydrides formed in situ from diacids played a key intermediate ahead of imides.

\section{Acknowledgements}

We thank the Universite de Rennes 1 and the Centre National de la Recherche Scientifique (CNRS). C. N. thanks the French Embassy in Thailand for a grant, J. W. acknowledges the China Scholarship Council (CSC) for a PhD grant.

Keywords: iron catalysis $\cdot$ hydrosilylation $•$ dicarboxylic acid • cyclic amines $\cdot$ one-pot

[1] Njardarson group. Top 200 Brand Name Drugs by Retail Sales in 2015 , https://njardarson.lab.arizona.edu/content/top-pharmaceuticals-poster, as of January 2020.

[2] Selected representative books and reviews, see: a) R. C. Larock in Comprehensive Organic Transformations: a Guide to Functional Group Preparation; Wiley-VHC, New York, 1989; b) A. Ricci in Modern Amination Method, Wiley-VCH Verlag GmbH \& Co. KGaA, Weinheim: New York, 2000; c) S. A. Lawrence in Amines: Synthesis, Properties and Applications, Cambridge University Press, Cambridge, 2004; d) A. Ricci in Amino Group Chemistry. From Synthesis to the Life Sciences (Ed: A. Ricci), Wiley-VCH Verlag GmbH \& Co. KGaA, Weinheim, 2008 e) P. Roose, K. Eller, E. Henkes, R. Rossbacher, H. Höke, Amines, Aliphatic, In Ullmann's Encyclopedia of Industrial Chemistry; WileyVCH: Weinheim, 2015, pp. 1-55; f) T. Kahl, K.-W. Schröder, F. R Lawrence, W.-J. Marshall, H. Höke, R. Jäckh, Aniline, In Ullmann's Encyclopedia of Industrial Chemistry, Vol. 3, Wiley-VCH: Weinheim, 2011, pp. 465-478; g) M. M. Heravi, Z. Kheikordi, V. Zadsirjian, M. Heydari, M. Malmir, J. Organomet. Chem. 2018, 861, 17-104; h) P. A Forero-cortés, A. M. Haydl, Org. Process. Res. Dev. 2019, 23, 14781483; For selected contributions on recent $\mathrm{C}-\mathrm{H}$ bond amination, see: $\mathrm{i}$ X. Wen, X. Li, X. Luo, W. Wang, S. Song, N. Jiao, Chem.Sci. 2020, 11, 4282-4287; j) Y-D. Du, C.-Y. Zhou, W.-P. To, H.-X. Wang, C.-M. Che Chem. Sci. 2020, 11, 4680-4686; k) S. Liang, X. Zhao, T. Yang, W. Yu, Org. Lett. 2020, 22, 1961-196; I) B. Plietker, A. Röske, Catal. Sci. Technol. 2019, 9, 4188-4197; m) K.-P. Shing, Y. Liu, B. Cao, X.-Y Chang, T. You, C.-M. Che, Angew. Chem. Int. Ed. 2018, 57, 11947 11951.

[3] For a recent review, see: A. Chardon, E. Morisset, J. Rouden, J. Blanchet, Synthesis 2018, 984-997.

[4] For selected reviews on amide hydrogenations, see: a) A. M. Smith, R. Whyman, Chem. Rev. 2014, 114, 5477-5510; b) S. Werkmeister, K. Junge, M. Beller, Org. Process Res. Dev. 2014, 18, 289-302.

[5] E. Balaraman, B. Gnanaprakasam, L. J. W. Shimon, D. Milstein, J. Am. Chem. Soc. 2010, 132, 16756-16758.

[6] a) R. Barrios-Francisco, E. Balaraman, Y. Diskin-Posner, G. Leitus, L. J. W. Shimon, D. Milstein, Organometallics 2013, 32, 2973-2982; b) J. M. John, S. H. Bergen, Angew. Chem. Int. Ed. 2011, 50, 10377-10380 Angew. Chem. 2011, 123, 10561-10564; c) M. Ito, T. Ootsuka, R. Watari, A. Shiibashi, A. Himizu, T. Ikariya, J. Am. Chem. Soc. 2011, 133, 4240-4242; d) R. Cabrero-Antonino, E. Aberico, H. J. Drexler, W. Baumann, K. Junge, M. Beller, ACS Catal. 2016, 6, 47-54; e) T. Miura M. Naruto, K. Toda, T. Shimomura, S. Saito, Sci. Rep. 2017, 7, 1586.

[7] A. A. Nunez Magro, G. R. Eastham, D. J. Cole-Hamilton, Chem. Commun. 2007, 3154-3156.

[8] J. Coetzee, D. L. Dodds, J. Klankermayer, S. Brosinsky, W. Leitner, A. M. Z. Slawin, D. J. Cole-Hamilton, Chem. Eur. J. 2013, 19, 11039-11050.

[9] J. R. Carbero-Antonino, E. Albericio, K. Junge, H. Junge, M. Beller, Chem. Sci. 2016, 7, 3432-3442.

[10] M.-L. Yuan, J.-H. Xie, Q.-L. Zhou, ChemCatChem 2016, 8, 3036-3040.

[11] M.-L. Yuan, J.-H. Xie, S.-F. Zhu, Q.-L. Zhou, ACS. Catal. 2016, 6, 36653669. 
[12] Y.-Q. Zou, S. Chakraborty, A. Nerush, D. Oren, Y. Diskin-Posner, Y. Ben-David, D. Milstein, ACS. Catal. 2018, 8, 8014-8019.

[13] a) D. Wei, C. Darcel, Chem. Rev. 2019, 119, 2550-2610; b) D. S. Mérel, M. L. T. Do, S. Gaillard, P. Dupau, J.-L. Renaud, Coord. Chem. Rev. 2015, 288, 50-68; c) N. S. Shaikh, ChemistrySelect 2019, 4, 6753-6777; d) A. Y. Khalimon, K. A. Gudun, D. Hayrapetyan, Catalysts 2019, 9, 490; e) J.-L. Renaud, S. Gaillard, Synthesis 2016, 48, 3659-3683.

[14] a) J. A. Garg, S. Chakraborty, Y. Ben-David, D. Milstein, Chem. Commun. 2016, 52, 5285-5288; see also: b) F. Schneck, M. Assmann, M. Balmer, K. Harms, R. Langer, Organometallics 2016, 35, 1931-1943; c) N. M. Rezayee, D. C. Samblanet, M. S. Sanford, ACS Catal. 2016, 6, 6377-6383; d) U. Jayarathne, Y. Zhang, N. Hazari, W. H. Bernskoetter, Organometallics 2017, 36, 409-416.

[15] For examples of recent reviews on iron-catalyzed hydrosilylation, see: a) H. Wen, G. Liu, Z. Huang, Coord. Chem. Rev. 2019, 386, 138-153; b) I. Bauer, H.-J. Knölker, Chem. Rev. 2015, 115, 3170-3387; c) M. D. Greenhalgh, A. S. Jones, S. P. Thomas, ChemCatChem 2015, 7, 190222; For representative recent papers, see: d) M.-Y. Hu, J. Lian, W. Sum, T.-Z. Qiao, S.-F. Zhu, J. Am. Chem. Soc. 2019, 141, 4579-4583; e) M.-Y. Hu, Q. He, S.-J. Fan, Z.-C. Wang, L.-Y. Liu, Y.-J. Mu, Q. Peng, S.-F. Zhu, Nat. Commun. 2018, 9, 221; f) B. Cheng, W. Liu, Z. Lu, J. Am. Chem. Soc. 2018, 140, 5014-5017; g) K. Zhu, M. P. Shaver, S. P. Thomas, Chem. Sci. 2016, 7, 3031-3035; h) J. Gui, C.-M. Pan, Y. Jin, T. Qin, J. C. Lo, B. J. Lee, S. H. Spergel, M. E. Mertzman, W. J. Pitts, T. E. La Cruz, M. A. Schmidt, N. Darvatkar, S. R. Natarajan, P. S. Baran, Science 2015, 348, 886-891; i) T. Bleith, H. Wadepohl, L. H. Gade, J. Am. Chem. Soc. 2015, 137, 2456-2459; j) A. M. Tondreau, C. C. H. Atienza, K. J. Weller, S. A. Nye, K. M. Lewis, J. G. Delis, P. J. Chirik, Science 2012, 335, 567-570.

[16] a) Y. Sunada, H. Kawakami, T. Imaoka, Y. Motoyama, H. Nagashima, Angew. Chem. Int. Ed. 2009, 48, 9511-9514; Angew. Chem. 2009, 121, 9675-9678; b) H. Tsutsumi, Y. Sunada, H. Nagashima, Chem. Commun 2011, 47, 6581-6583.

[17] S. Zhou, K. Junge, D. Addis, S. Das, M. Beller, Angew. Chem. Int. Ed. 2009, 48, 9507-9510; Angew. Chem. 2009, 121, 9671-9674.

[18] D. Bézier, G. T. Venkanna, J.-B. Sortais, C. Darcel, ChemCatChem 2011, 3, 1747-1750.

[19] B. Blom, G. Tan, S. Enthaler, S. Inoue, J. D. Epping, M. Driess, J. Am. Chem. Soc. 2013, 135, 18108-18120.

[20] A. Volkov, E. Buitrago, H. Adolfsson, Eur. J. Org. Chem. 2013, 20662070.

[21] S. Das, B. Wendt, K. Möller, K. Junge, M. Beller, Angew. Chem. Int. Ed. 2012, 51, 1662-1666; Angew. Chem. 2012, 124, 1694-1698.

[22] a) D. Wei, C. Netkaew, V. Carré, C. Darcel, ChemSusChem 2019, 12, 3008-3012; b) D. Wei, C. Netkaew, C. Darcel, Adv. Synth. Catal. 2019, 361, 1781-1786; c) D. Wei, C. Netkaew, C. Darcel, Eur. J. Inorg. Chem. 2019, 2471-2487;

[23] For representative examples, see: a) K.-i. Fujita, T. Fujii, R. Yamaguchi, Org. Lett. 2004, 6, 3525-3528; b) A. J. A. Watson, A. C. Maxwell, J. M. J. Williams, J. Org. Chem. 2011, 76, 2328-2331; c) S.-I. Murahashi, K. Kondo, T. Hakata, Tetrahedron Lett. 1982, 23, 229-232; d) T. Naota, H. Takaya, S.-I. Murahashi, Chem. Rev. 1998, 98, 2599-2660; e) R. A.
Abbenhuis, J. Boersma, G. van Koten, J. Org. Chem. 1998, 63, 4282 4290; f) Y. Tsuji, Y. Yokoyama, K.-T. Huh, Y. Watanabe, Bull. Chem. Soc. Jpn. 1987, 60, 3456-3458; g) K. Yuan, F. Jiang, Z. Sahli, M. Achard, T. Roisnel, C. Bruneau, Angew. Chem. Int. Ed. 2012, 51, 8876-8880 Angew. Chem. 2012, 124, 9006-9010; h) Q. Zou, C. Wang, J. Smith, D. Xue, J. Xiao, Chem. Eur. J. 2015, 21, 9656-9661; i) W. He, L. Wang, C. Sun, K. Wu, S. He, J. Chen, P. Wu, Z. Yu, Chem. Eur. J. 2011, 17, 13308-13317; j) M. H. S. A. Hamid, C. L. Allen, G. W. Lamb, A. C Maxwell, H. C. Maytum, A. J. A. Watson, J. M. J. Williams, J. Am. Chem. Soc. 2009, 131, 1766-1774.

[24] a) R. I. Khusnutdinov, A. R. Bayguzina, R. S. Asylbaeva, R. I. Aminov, U. M. Dzhemilev, ARKIVOC 2014, 341-350; b) A. Afanasenko, S. Elangovan, M. C. A. Stuart, G. Bonura, F. Frusteri, K. Barta, Catal. Sci. Technol. 2018, 8, 5498-5505.

[25] W. Tan, C. Li, J. Zheng, L. Shi, Q. Sun, Y. He, J. Nat. Gas Chem. 2008, 17. 383-386.

[26] Y. Du, S. Oishi, S. Saito, Chem. Eur. J. 2011, 17, 12262-12267.

[27] For selected examples for the synthesis of cyclic amines via hydrogen borrowing methodology, see: a) T. Yan, B. L. Feringa, K. Barta, Nat. Commun. 2014, 5, 5602; b) T. Yan, B. L. Feringa, K. Barta, ACS Catal. 2016, 6, 381-388; c) Z. Yin, H. Zeng, J. Wu, S. Zheng, G. Zhang, ACS Catal. 2016, 6, 6546-6550.

[28] A. Afanasenko, R. Hannah, T. Yan, S. Elangovan, K. Barta, ChemSusChem 2019, 12, 3801-3807.

[29] I. Sorribes, K. Junge, M. Beller, J. Am. Chem. Soc. 2014, 136, 1431414319.

[30] Y. Shi, P. C. J. Kamer, D. J. Cole-Hamilton, M. Harvie, E. F. Baxter, K. J. C. Lim, P. Pogorzelec, Chem. Sci. 2017, 8, 6911-6917.

[31] B. Schäffner, F. Schäffner, S. P. Verevkin, A. Börner, Chem. Rev. 2010 110, 4554-4581.

[32] R. M. Lanigan, T. D. Sheppard, Eur. J. Org. Chem. 2013, 7453-7465.

[33] a) S. Li, K. Huang, J. Zhang, W. Wu, X. Zhang, Org. Lett. 2013, 15 1036-1039; b) W. Wang, C. Ding, Y. Li, Z. Li, Y. Li, L. Peng, G. Yin Angew. Chem. Int. Ed. 2019, 58, 4612-4616; Angew. Chem. 2019, 131, 4660-4664.; c) S. P. Shan, X. Xiaoke, B. Gnanaprakasam, T. T. Dang, B. Ramalingam, H. V. Huynh, A. M. Seayad, RSC Adv. 2015, 5, 44344442.

[34] a) H. Li, L. C. Misal Castro, J. Zheng, T. Roisnel, V. Dorcet, J.-B. Sortais, C. Darcel, Angew. Chem. Int. Ed. 2013, 52, 8045-8049; Angew. Chem 2013, 125, 8203-8207; b) S. Quintero-Duque, H. Li, L. C. Misal Castro, V. Dorcet, T. Roisnel, E. Clot, M. Grellier, J.-B. Sortais, C. Darcel, Isr. J. Chem. 2017, 57, 1216-1221; c) M. Bhunia, P. K. Hota, G. Vijaykumar, D. Adhikari, S. K. Mandal, Organometallics 2016, 35, 2930-2937.

[35] a) G.-B. Liu, H.-Y. Zhao, Beilstein J. Org. Chem. 2008, 4, 1-6; b) G.-B. Liu, Synlett 2006, 1431-1433; c) G.-B. Liu, H.-Y. Zhao, T. Thiemann, Adv. Synth. Catal. 2007, 349, 807-811; d) D. Wei, R. Buhaibeh, Y. Canac, J.-B. Sortais, Org. Lett. 2019, 21, 7713-7716. 
WILEY-VCH

\section{Entry for the Table of Contents}

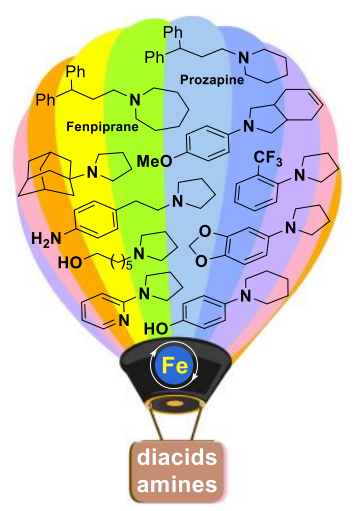

A ride in an "iron" balloon: a novel strategy for building $N$-substituted cyclic amines is reported via iron catalyzed one-pot hydrosilylation of dicarboxylic acids with amines, using silanes as hydride source. 50 examples of amine derivatives, including drug molecules Fenpiprane and Prozapine, were prepared in good yields with dimethyl carbonate as a green solvent. 